\title{
THE COLLABORATIVE STRATEGIC READING (CSR) THROUGH STUDENTS' READING COMPREHENSION
}

\author{
Muziatun \\ Department of English Language, Faculty of letters and culture, \\ State University of Gorontalo, Indonesia \\ Email: muziatun@ung.ac.id \\ Maryam Katili \\ Department of English Language, Faculty of letters and culture, \\ State University of Gorontalo, Indonesia \\ Email: maryamkatili12@gmail.com
}

\begin{abstract}
APA Citation: Muziatun, \& Katili, M. (2020). The collaborative strategic reading through students' reading comprehension. Indonesian Journal of Learning and Instruction, 3(1), 43-50. doi: 10.25134/ijli.v3i1.3007.
\end{abstract}

Received: 02-02-2020

Accepted: 07-03-2020

Published: 01-04-2020

\begin{abstract}
This research aim to find out to find out (1) Whether the implementation of Collaborative Strategic Reading (CSR) increase the students' achievement in reading comprehension at the students of MA Al-Huda Gorontalo. (2) Which aspects of reading get the highest increase in the implementation of Collaborative Strategic Reading (CSR).This research conducts quantitatively which used per-experimental research. The sample of this research is 20 students of the second grade at MA Al-Huda Gorontalo. Reading comprehension test, specifically exposition text is used to collecting the data. The test was an objective test and it used to collecting the data pre-test and the post-test. The result of the pre-test was 261 and the posttest was 341 . The hypothesis found that the $T_{\text {count }} \geq T_{\text {list }}$ by the value $9,756 \geq 2,093$. It proves that the Hypothesis $\left(\mathrm{H}_{1}\right)$ is accepted. Thus, the conclusion is the Collaborative strategic reading (CSR) increases the students' reading comprehension at MA Al-Huda kota Gorontalo.
\end{abstract}

Keywords: Collaborative Strategic Reading (CSR); reading comprehension.

\section{INTRODUCTION}

Reading is a receptive skill in English. This is the basic English that being the important one to learn, because it is the fundamental ways of getting information in our society and academic setting in particular. Reading itself is a process to compose the meaning of the text it could be novels, magazines, children's storybooks, and newspaper. These texts can be presented by various illustrations, diagrams, or graphics.

Reading by understanding the text called reading comprehension. Nuriati (2015) in her Journal stated that comprehension is the understanding of the meaning of the written material and covers the conscious strategies that lead to understand. So, reading comprehension means understanding what the reader has been read. It is an active process that not only depends on comprehension skills but also the reader's experiences and prior knowledge. Dalman (2013) as cited in Simbolon and Marbun (2017) stated that reading comprehension is a cognitive process which plays an important role in order to understand the text. Related to the statement, the reader must know the meaning. Another statement from Gani, et al., (2016) defined that reading comprehension is a complicated, cognitive meaning constructing process which involves the interaction of the reader the text, and the context. It is is a reading activity that seeks to comprehend the text: 1) the ability to grasp the meaning of words and expressions used by the author, 2) the ability to grasp explicit meaning and implied meaning, 3) the ability to make conclusions (Simbolon and Marbun, 2017)

The study conducted in MA Al-Huda in July 2018 by interviewed the teacher and the students. Based on the interview, it found that the students at the school had problems with their reading comprehension, because they just learned about the material of the reading without knowing the context of the text. It was a common problem that existed in a teaching reading. It is because teacher taught English without giving them a strategy about how to understand the text.

Nuttal (1982) as cited in An Nisaa Rahmadani (2017) said that there are five aspects which help the students to comprehend the English text well, it is: (1) Main Idea; it is the main point of the paragraph. The main idea of the paragraph is the author's idea about the topic. It is a complete sentence that includes both the topic and the idea 
that others wish to express about the topic. Miami (2005) as cited in Rauzatul and Rosnani (2016) defined that main idea is the central, or most important idea in a paragraph or passage.

Reading for finding the main idea is a skill that requires careful reading a text to identify the main point without worrying about unnecessary detail, (2) Identifying Specific Information; it is the supporting sentence of the paragraph. The supporting sentence includes definition, examples, cause and effect, fact and opinion, comparison, and quotation, (3) References; it is a relation that obtains between expressions and what speakers use expressions to talk about. References are words or phrases. They use before or after the reference in the reading material. The author uses reference is to create cohesion between before and after the paragraph. It also used to avoid unnecessary repetition of words or phrases in a reading text. The references mostly are pronouns or noun phrases, such as I, you, they, that, this, those, himself, herself, etc, (4) Inference; sometimes the topic of a text may not be stated directly anywhere. The readers must look for the clues and try to guess what the text is about. Kurland (2000) as cited in Rauzatul and Rosnani (2016) defined that inference is a mental process by which the reader reaches a conclusion based on specific evidence of the text. So, inference defines as an understanding something from an indirect statement (5) Understanding the Difficult Vocabulary; vocabulary in reading is clearly understood: vocabulary knowledge, the understanding of word meanings and their use, contributes to reading comprehension and knowledge building. On the reading test, the question of understanding difficult vocabulary can be the synonym, the antonym, or the meaning of the phrase.

Collaborative Strategic Reading (CSR) is a reading comprehension practice which combines two instructional elements; that is modified reciprocal teaching and cooperative learning or students pairing. Reciprocal teaching of CSR means the teacher and the students are work together to questioning, predicting, clarifying, and summarizing the reading text by the steps of CSR. Meanwhile, the concept of this strategy is cooperative learning of working in a small group. Klingner and Vaughn (1998) as cited in Zagoto and Impiani (2016) and Rahayu (2018) stated that CSR is an excellent technique for teaching students reading comprehension by working cooperatively. Cooperative learning can improve students' oral communication and develop students' social skills. It happens because all of the students get the opportunity to speak in the learning process even the students who never speak in the class. At least, the students share their idea among the members of the group, giving feedback, and reporting the result. It makes the learning process active and effective.

Based on the background presented, The Collaborative Strategic Reading (CSR) was applied to improve the students' reading comprehension in MA Al-Huda Gorontalo. Hence, the research questions are:

1. Whether the implementation Collaborative Strategic Reading (CSR) increased the students' achievement in reading comprehension especially the students of MA Al-Huda?

2. Which aspects of reading get the highest increase in implementation of Collaborative Strategic Reading (CSR)?

Based on Klingner and Vaughn (1998) as cited in Rahayu (2018), Collaborative Strategic Reading is an excellent technique for teaching students reading comprehension and building vocabulary and also working together cooperatively. Furthermore, Lee (2016) defines Collaborative Strategic Reading (CSR) as an approach to reading comprehension strategy instruction combined with cooperative learning; teachers provide students with the meta-cognitive knowledge of reading strategies through explicit instruction". In short, Collaborative Strategic Reading is a strategy to teach reading comprehension through cooperative learning..

The Cooperative learning itself is a teaching and learning process that involves the use of small groups that enable students to work together in it to maximize their own learning and learning from each other Johnson, D., Johnson, RT \& Holubec EJ (2012). It is a learning model which the system of learning works in small groups of five students by collaboratively so it can stimulate the students to be more passionate in learning Slavin (in Isjoni, 2010). The students divided into small group which consisted of 4-5 students so, the students can discuss with each other, express opinions to solve the problems encountered. The goals of Collaborative Strategic Reading are to improve reading comprehension and increase conceptual learning in ways that maximize students' involvement (Rahayu, 2012)

Collaborative Strategic Reading consisted of four reading comprehension. Klingner, et al. (2012) as quoted by Gani, et al. ( 2016) divided CSR into before reading (Preview), during 
reading (Click and Clunk, and Gist strategies), and after reading (Wrap up). The strategies of CSR as follows:

\section{Preview}

Preview is designed to activate the background knowledge of students and to make predictions about the text before they start reading. In this step, teacher guides the students to activate their prior knowledge by use the title, topic, or the picture that exist from the reading text. The teacher prompts students to brainstorm what they already know about the topic and invites them to share ideas with their classmates (Gani, et al., 2016).

\section{Click and Clunk}

Click and clunk is implemented while reading. This step asks the students to observe words, sentences, or concept that they do not understand. To understand difficult words or sentences students need to look at the context of the sentence before or after the difficult word by used a fix-up strategy. The fix-up strategies includes: (1) Re-read the sentence, where there is a difficult word (Clunk) and look for the essence of the sentence to understand the part, (2) Read back the difficult sentence, the sentence before and after. (3) Break the word apart and look for a prefix, suffix, or a root word; and (4) Look for the cognates that makes sense. By click and clunk, students solve the problem by understanding difficult words, so students can learn independently but still under the guidance of the teacher (Gani, et al., 2016)

\section{Get the Gist}

After students repair their clunks, they do the next step, Get the Gist. Get the gist known as a way to find the main ideas and practice when reading texts. One way to identify the main idea is to answer the following questions: (a) "Who or what is it about?" and (b) "What's most important? In addition, students are taught to respond to ten words or less, so in essence they convey the most important ideas and those that are not detailed need not be conveyed. It purposes of get the gist is to teach students to identify the most important information in the paragraphs or sections of text they have just read, in other words to determine Main idea (Gani, et al., 2016).

\section{Wrap Up}

Wrap up is the last step that teaches students to produce questions and ideas to review the main ideas in the text they have read. The wrap up consists of two activities: (a) generating questions, and (b) reviewing the reading. That means that in the wrap-up students make questions about reading, after that they review the main ideas in the reading and then conclude the reading they have read. Wrap up purposes to teach students to identify the most significant ideas in all the parts they have read and then help them by understanding and remembering what they have learned (Gani, et al., 2016).

\section{METHOD}

This research conducted quantitatively which used one group pre-test - post-test design. There was a group or class that I had giving a treat and taught by using CSR method. The group named the experimental group. The group also had a test before (pre-test) and after (post-test) treatment. The result is used to analyze and compare the student's achievement between before and after treat by using CSR.

The design of the pre-experimental design with the type of one group pre-test and post-test design can be described by Sugiyono (2015) as follows:

\begin{tabular}{lcl}
\hline & \multicolumn{2}{c}{ Experimental Group } \\
\hline Pre-test & Treatment & Post-test \\
$\mathrm{O}_{1}$ & & $\mathrm{O}_{2}$ \\
\hline
\end{tabular}

Furthermore, to determine the sample of this research, I used purposive sampling to take my sample of research. I choose the science class of the second graduate class in MA Al-Huda which has 20 students to be the sample of the research.

The instrument of the research was a reading comprehension test which an exposition text. The test was multiple choices and it consisted of 23 numbers of questions.

There are a few steps in the collecting. The steps explained how the way I collect the data from the sample. It included there-test, Treatment, and the last is Post-Test.

\section{Pre-Test}

First, I gave a reading comprehension text before the treatment of CSR begun. The students answered the text by using their proper knowledge. It analyzed he students' prior knowledge before being taught by using CSR

\section{Treatment by using CSR Method}

The treatment was a teaching reading comprehension by using CSR which focused on Exposition text. It was given to the students on the class that has chosen as the sample after they got the pretest. The treatment occurred for six meetings which take about $2 \times 45$ minutes for each meeting.

There were six reading materials of exposition text that which applied for the 
treatment. Each meeting had one new reading material. The titles for each meeting were: First meeting: "Global Warming", Second meeting: "drug users", Third meeting: "cars and accidents", Forth meeting: "hand-phone should be banned in school", Fifth meeting: "fuel price", The last meeting: "why students should manage their stress". These reading materials were applied to the students by using CSR.

\section{Post-Test}

The Post-Test will be given by me after I treat the students' reading comprehension by uses the CSR method. By using the result of the test, I will analyze the result of the treatment in the learning process. So, I can see whether the CSR strategy gives an effect on the students reading comprehension or not.

The data was analyzed by using T-Test Formula. It is used to compare two different sets of values (pre-test score and post-test score). The result of the $\mathrm{T}$-test determined the result of implementation of CSR strategy. T-test is generally applied to the normal distribution which has a small set of values. The formula T-test as follow:

$$
t=\frac{M d}{\sqrt{\frac{\sum(x d)^{2}}{n(n-1)}}}
$$

Md : the different mean score between pretest and post-test

xd $\quad$ : the derivation of each sample (d-Md)

$\sum x d 2$ : the total of square derivation

$\mathrm{n} \quad$ : number of sample

\section{RESULTS AND DISCUSSION}

The data presented the data pre-test, treatment and post-test from. It aimed find out the students' achievement between before and after the implementation of CSR. The data as follows:

\section{Description of the pre-test}

The result of the pre-test showed the total number of the correct answer of 20 students was 261. The highest score of 20 students was 17 and the lowest score was 7. The result of students' score of pre-test explained on the table distribution frequency below.

\begin{tabular}{cccc}
\multicolumn{4}{c}{ able 1. Distribution frequency of pre-test } \\
\hline No & Interval & Frequency & Precentage \\
\hline 1 & $7-8$ & 1 & $5 \%$ \\
2 & $9-10$ & 3 & $15 \%$ \\
3 & $11-12$ & 3 & $15 \%$ \\
4 & $13-14$ & 7 & $35 \%$ \\
5 & $15-16$ & 3 & $15 \%$ \\
6 & $17-18$ & 3 & $15 \%$ \\
\hline \multicolumn{5}{c}{ Total } & 20 & $100 \%$ \\
\hline
\end{tabular}

Based on the table distribution frequency of pretest, the lowest score of pretest was in 7-8 and the highest score was 17-18. The table also shows only 1 student or 5\% students got score 7-8, meanwhile most of the students got score 13-14 which had 7 students or $35 \%$ from the total students of the class. The students' pre-test based on five aspects of reading describes below.

\section{Main idea}

There are 7 questions of main idea in reading comprehension test which got 1 score for each correct answer. So, if all the students (20 students) answer 7 questions correctly, the total score for the main idea is 140 . The pre-test results showed the total score of main idea was 81 , which mean the correct answer in pre-test is $62 \%$ from the total score should be.

\section{Identify specific information}

In the aspect of identify the specific information, there are 5 questions on the reading test. The total score in this aspect is 100 . The result of the students' answers on the pre-test on this aspect was 58 or $58 \%$ of the total score.

\section{References}

Aspects of reference have 4 questions on reading this test. The total score in this aspect is 80 . The score of pre-test was 55 or $69 \%$ from the total score of the aspect

\section{Making inference}

Aspects of making inference only have 2 questions on the reading test this. Total score for the aspects is 20 . The total pre-test score was 14 ; it was only $35 \%$ of the total score.

\section{Understanding the Difficult Vocabulary}

In the aspect of understanding difficult vocabulary, the total score of 5 on the reading comprehension test is 100 . The total score from the pre-test was 47 or $47 \%$ of total score 100 . 


\section{Description of the treatment}

The CSR was applied to the students for six meetings. The description of students improving for each meeting describe below:

\section{The first meeting}

I divided the students into three groups. Each group consisted of 4-5 students. Then I ask the students to understand the contents of the text of "global warming" that exist on the textbook in page 44 without the using the CSR. It aimed to make early predictions of students' ability to understand the content of the text in a group before the application of CSR. Then students have difficulty solve the tasks because they confused it. Some of them are desperate to open a Google translate on the phone. Whereas the mobile phones are banned to bring in schools but the students do not obey the rules.

\section{The second meeting}

The second meeting started to apply the steps of the CSR. First, the students rejoin into the group that has been formed at the first meeting. The second meeting the students are required to understand the contents of the text reading comprehension "drug users".

This meeting became the first implementation of CSR for the students. For the first implementation of CSR, students were easy to catch about what they learned. It is because the students were familiar about the topic of drug users.

So, they could have guessed the topic of the text as well. But in the next steps, the students became the cluck expert and became the gist expert was hard to comprehend the text. However, the students still translated the text by using a dictionary or Google translate.

\section{The third meeting}

The reading material at the third meeting was "cars and accidents". At this meeting, the students were not be able to use Google translate. So they must comprehend the text pure based on CSR strategy.

In fact, at the preview step, students were easy to understand. It is also because the topic that has been given was familiar for the students.

But in the click and clunk and get the gist steps, the students little difficulty because there are some words that was foreign for them so I guided them to translating the difficult words.
Indeed, the warp-up strategy did not apply effectively.

\section{The fourth meeting}

The reading material at the third meeting was "hand-phone should be banned in school". At this meeting, the students were accustomed about the CSR but they still hard to comprehend the reading text without Google Translate.

The topic about "hand-phone should be banned in school" also is an easy topic for the students. So, the students predicted about what they learned easily. But the click and cluck and get the gist steps were being longer because the "hand-phone should be banned in school" is a long text and the students think that the words of the text were harder than the other texts.

So they work really hard to comprehend the text. Finally, the time was not enough and it was continued to the next meeting.

\section{The fifth meeting}

The reading material at the third meeting was "fuel price". The topic this of meeting was harder than previous meeting. So, I helped them by explaining what the topic is; then, the students begun to previewing the text. In the click and cluck and get the gist steps, the students were accustomed to comprehend the test without using Google Translate even they still work hard to comprehend the text. But the implementation of CSR was being effectively. It showed from their students' work sheet; the students could answer some questions that I gave to the students.

\section{The sixth meeting}

Reading material at the third meeting is "Students should manage their stress". The reading text of this meeting was a longer text but the students comprehended the text well. The students also easy to implemented the CSR step-by-step. The implementation of the CSR was effective for teaching reading comprehension.

\section{The description of the post-test}

After the students being taught by using CSR, the total score of the students post-test is 341 and the mean score is 17. From the result of the posttest, the highest score was 22 and the lowest score was 12. So, the table distribution frequency of the students' post-test result presents on the table below.

Table 2. Distribution frequency of post-test

\begin{tabular}{cccc}
\hline No & Interval & Frequency & Percentage \\
\hline 1 & $12-13$ & 2 & $10 \%$ \\
2 & $14-15$ & 3 & $15 \%$
\end{tabular}




\begin{tabular}{cccc}
3 & $16-17$ & 7 & $35 \%$ \\
4 & $18-19$ & 5 & $25 \%$ \\
5 & $20-21$ & 2 & $10 \%$ \\
6 & $22-23$ & 1 & $5 \%$ \\
\hline & Total & 20 & $100 \%$ \\
\hline
\end{tabular}

The students' score divided into 6 interval classes. Based on the table distribution frequency of the post-test score, most of the students got score 16-17. It could be seen from the table; there were $35 \%$ students on the class got score 16-17.

Meanwhile, only 1 student got the higher interval score. The table frequency of the pre-test and the posttest above represented the students' achievement between before being taught by using CSR and after being taught by using CSR.

Known total number of scores for 20 students is 460. In the pre-test, the number of correct answers was 261 which the percentage $57 \%$ of the total score then after being given the treatment of CSR the number of correct answers in the posttest became 341 or $74 \%$ of the total score. So, the students' achievement increased $17 \%$.

Based on the comparing between the students' achievement of the pre-test and the posttest, it could be conclude that the Collaborative Strategic Reading increased the students' achievement in reading comprehension. The students' pre-test based on five aspects of reading describes below.

\section{Main idea}

After the students were given the treatment of CSR, the post-test score for the main idea increased 24 points or $17 \%$ increase from the pretest results. It can be compared with the pre-test score is $81(62 \%)$ and post-test scores are the result of $111(79 \%)$.

\section{Identify specific information}

On the aspect of identify specific information, the post-test score was 74 (74\%). If it was compared with the pre-test score, the score of post-test increased as much as $16 \%$ from the pre-test

\section{References}

On the questions test of aspects reference, the post-test score was $63(79 \%)$ where the score was increased to $10 \%$ from the pre-test of $55(69 \%)$. It could be seen from the comparison on the graph to pre-test and post-test.

\section{Making inference}

For question test by aspect of the making inference, post-test results of students rose 13 points, or $33 \%$ of the pre-test. It can be seen from the comparison of both the graphic aspects of reading; the pre-test score of making inferences is $35 \%$ (with the total score 14 point) to $68 \%$ (with a total score of 27). To more details, please see the graphic of the pre-test and post-test.

\section{Understanding difficult vocabulary}

The last aspect of reading is understands the difficult vocabulary. For questions aspect of understanding the difficult vocabulary of a total score of 100 , the post-test score is 66 or $66 \%$ from the total score. So, the score for post-test increases 19 points (with a percentage of 19\%) of the score results of the pre-test

Based on the comparing the pre-test and the post-test graphs on each aspects of reading, it could be concluding that: the main idea increased $17 \%$, the specific information increased $16 \%$, the references increased $10 \%$, and the inference increased $33 \%$ and the understanding the difficult vocabulary increased $19 \%$.

So, it can be concluded that this aspect of making inferences got the highest increased score on the post-test that is equal to $33 \%$ of the pretest. In other words, the CSR can improve the ability of students, especially in the aspect of making inference. Meanwhile, the CSR is not affecting in the aspect of reference. It is evident from the increase in scores contained in the reference aspect that is only $10 \%$.

The success of CSR in increase students' reading comprehension ability cannot be separated from these two advantages of CSR as stated by Abidin (2012) in Mardiani (2018). First, CSR not only teaches students cognitively, but also meta-cognitively. CSR is not only teaching readers with cognitive approach but also teaching readers how to use the strategies metacognitively. In CSR, readers are engaged to generate their pre-existing knowledge by previewing overall look of the text while looking at non linguistics features such as; charts, pictures and diagrams. Through this process, the readers predict what they will learn from the text CSR provides readers on how to decode the words, letters, take a note in the margins, underlining as part of cognitive strategies which are very fundamental factors in comprehending the texts. In this approach, reading is meant to be a process of decoding; identifying letter, words, phrases and then sentences in order to get the meaning. It usually refers to an information processing view an individual's psychological functions. Other 
interpretations of meaning of cognition link it to the development of concepts, individual minds, groups, and organizations. Then, CSR is taught meta-cognitively by principle of planning, selfmonitoring, and evaluating. Eleni Mitsea and Athanasios Drigas (2019) define meta-cognitive strategies in three ways: Planning, self-monitoring and evaluating or think about thinking. Planning is to have reading purpose in mind and to read the text in the terms of this purpose, so the readers are more selective and focus the desired information. Self-monitoring is to regulate the reading process and use the strategy at the right time. Evaluating is the reform phase of reading process such as: changing the strategy if necessary, control whether the purpose is reached or not.

The second is CSR works by cooperative learning method. Céline Buchs and Fabrizio Butera (2015) stated that Cooperative learning represents situations in which teachers structure group work with the aim to maximize both social and cognitive outcomes. By learning cooperatively, students have opportunity to discuss and share the ideas among the members of the groups as well as develop their social skills and the students also solved the problem together and also built the social skill at the same time.

\section{CONCLUSION}

After conducting the research for a few months, finally the research could figure out the research question number one in which is the Collaborative Strategic Reading (CSR) can increase then students' ability in reading comprehension. The research conducted in MA Al-Huda Gorontalo proofs the Collaborative Strategic Reading (CSR) increases the students' achievement in reading comprehension. It proved by seeing the result of this research; the students obtained $57 \%$ in the pre-test. Meanwhile, total score in post-test, students obtained $74 \%$. So, the students' achievement in post-test increases $17 \%$ from the pre-test. In the other words, the students' achievement in reading comprehension test is increase before and after being taught by using CSR method.

It also proved by using the Hypothesis result. Hypothesis (H1) was CSR method can increase students' English learning achievement in reading comprehension. (H1) accepted if tcount $>$ tlist. From this research, the hypothesis verification was 9,75>2,093 It means the CSR can increase the students reading comprehension.

In addition, while the CSR can increase the students' ability, it also specifically can improve their ability in aspect of making inference a reading comprehension. It can be seen from the result of second analysis; between the five aspects of reading, the aspect of making inference experiencing the highest increases in the amount of $33 \%$, or it increases 13 points from the score of the pre-test. It could be seen the data pre-test and the post-test on each aspect of reading in which the test results for the question about this aspect previously received the lowest score among all aspects of reading only $35 \%$ of the total score. But after the students treat with CSR, the results of post-test scores on the aspect of making inferences increased to 68\% (refer to the Data finding).

In the other contrarily, the CSR does not really improve the students' ability on the aspect of reference in reading comprehension. It is because the students score on the post-test result of this aspect only increase 10\% from the pre-test. In sum up, the result of this research is the CSR effective to increase of the students' abilities in reading comprehension. It gave a positive impact for the students on their ability in reading comprehension.

\section{REFERENCES}

Buchs, C., \& Butera, F. (2015). Cooperative learning and social skills and development. Collaborative Learning: Developments in Research and Practice, 201-217.

Fitriani, S. S. (2015). Improving reading comprehension of Acehnese EFL students. EFL Students' Reading Comprehension Problems: Linguistic and Non-Linguistic Complexities, 311.

Gani, S. Y. (2016). Progressive Outcome of Collaborative Strategic Reading to EFL Learners. Kasetsart Journal of Science, 37, 144-149.

Jannah, R., \& Sahardin, R. (2016). The effect of using Directed Reading Thinking Activity (DRTA) strategy to improve students' reading comprehension. English Education International Conference (EEIC), 1(2), 261-265.

Mardiani, S. (2018). Research Paper:The Strengths and Weaknesses of Collaborative Strategic Reading (CSR) in Teaching Reading Comprehension. Karawang, Indonesia: Uniersity of Singaperbangsa Karawang.

Mitsea, E., \& Drigas, A. (2019). A Journey into the Metacognitive Learning Strategies. International Journal of Online and Biomedical Engineering (iJOE) , 15(4).

Nuriati. (2015). Improving students reading comprehension by using buzz group technique. E-journal of English Language Teaching Society (ELTS), 3(2), 115-122.

Rahayu, U. (2018). The Effectivenes of Collaborative Strategic Reading (CSR) to Enhance the 
Muziatun \& Maryam Katili

The Collaborative Strategies Reading (CSR) through students' reading comprehension

Students' Achievement in Reading Comprehension of Recount Text. Salatiga: State Institue for Islamic Studies (IAIN) Salatiga.

Simbolon, N., \& Marbun, I. (2017). Implementation of Sq4r Model to Increase Reading Comprehension Ability of Elementary Students. Advances in Social Science, Education and Humanities Research, 118, 999-1003.

Sugiyono. (2015). Metode Penelitian Pendidikan. Bandung: Alfabeta. 